\title{
The Character of Rip van Winkle: Representation of Disappearing Cultural Identity
}

\author{
MAGDALENA BAGA \\ Universitas Negeri Gorontalo \\ magdalena.baga@ung.ac.id
}

\begin{abstract}
The purpose of this research is to explore how an ethnicity is represented in a story that has a historical setting and how this ethnic group was placed in American history. The short story of Washington Irving, "Rip Van Winkle", published in 1819, was very popular in America. This story was recycled in the form of stories for children, made into plays, etc. What Americans always remember about Rip Van Winkle character is his laziness. The story of "Rip Van Winkle" is traced through Stuart Hall's Representation theory. This theory states that representation can give meaning to an identity, and the New Historicism method is used to uncover that fictional stories are tied to the world that produced them. The result shows that Rip's character is a representation of Dutch ethnicity who felt losing their cultural identity. Rip's character in the story is a representation of Dutch New York ethnicity, and he was the main character in the story who was narrated as a lazy man. Thus, what always presents in America's memory is the lazy Dutch because of the representation of the character of Rip, but the other characters who were narrated less in the story are not remembered, even though they played a role in establishing America.
\end{abstract}

Keywords: representation; cultural identity; new historicism; american history; dutch ethnicity

\section{INTRODUCTION}

Washington Irving, an early American writer, was famous for his fictions which always depicted Dutch ethnic in New York. Irving had written about the lives of the Dutch people in the 17th-18th century near the Hudson River, North America (Funk, 2009, 123). His work that was centered on telling Dutch people in America was A History of New York, published in 1809 (Kunitz, 1977; Pancost, 1987). This work was not Irving's first work, but he began to be noticed and became popular in America, especially in New York City, as a literary writer on this work. This is due to the choice of the subject of the narrative in his story, namely the Dutch New York community.

Ten years after the publication of A History of New York (Kunitz, 1977; Pancost, 1987), Washington Irving produced his work The Sketch Book of Geoffrey Crayon, Gent in 1819 in the form of a collection of short stories. His name had risen to be known to Europe because of the work of The Sketch Book. The American public's interest in this work was mainly due to the existence of two stories depicting the life of Dutch society in America in the 18th century, namely "Rip van Winkle" and "The Legend of Sleepy Hollow". The short story "Rip van Winkle" describes the life of the Dutch people in America during the transitional period when it was still a British colony, and also during the American independence. Meanwhile, "The Legend of Sleepy Hollow" describes the life of the Dutch people in a small village in America in the post-independence era (Baga, 2020, 237). 
His creativity by using American elements, especially in the setting of the story on his work, makes Irving's work different. It mirrors the characteristic of America as in his "Rip Van Winkle" and "The Legend of Sleepy Hollow". He used elements of traditional folklore related to Dutch culture in New York. He re-created Dutch folklore, which consisted of typical people's behavior, beautiful descriptions, ghost stories, jokes, and all humor reflecting the spirit of the new American culture, so that Irving was seen as typical America legend stories maker (Baga, 2020, 238; Funk 2005).

All of these short stories tell the elements of Dutch ethnic life in New York during the British colonization, American independence, and the post-independence era. These stories are told in the form of mystical and supernatural stories (Baga, 2020, 237). The stories in Irving's short stories which are related to the Dutch ethnicity, almost always refer to the life of the Dutch people in the era of the Dutch governors who controlled New Netherland. The place, later called New York, was described at least similar in the picture of the cultural setting to that of the governors who were depicted in the story A History of New York. This implies as if the short stories are a continuation of A History of New York, which described the lives of the Dutch in New York. Moreover, all the short stories about the Dutch have a permanent narrator, namely Knickerbocker.

The short stories written by Irving show the feud between the Dutch and the Yankees, both implicitly and explicitly (Ringe, 1967). Yankee is the name for the descendants of British puritans who occupied the Connecticut area, New England, a British royal colony in the 17th century. However, the most explicit feud is described in A History of New York, namely the struggle for territory and space between the Dutch who occupied the colonies of New Netherland on the Hudson river, and Yankee that lived across the Connecticut river was so visibly depicted (Baga \& Budianta, 2018, 260).

These Dutch New York were actually mentioned in Salmagundi published in 1807, a work in the form of a literary magazine written by Washington Irving, William Irving, and James Kirke Pulding, the last mentioned was a Dutch New Yorker. James Kirke Paulding wrote this section that briefly described the existence of the Dutch diaspora community in New York, and it inspired Washington Irving to write about the Dutch community in New York (Roth 1976,123; Bradley 2009, 26). Especially, with the publication of The Sketch Book which contains the stories of "Rip van Winkle" and "The Legend of Sleepy Hollow", Irving was considered to be a creator of American legends and myths, so that his works depicting the life of Dutch ethnicity on the banks of the Hudson River in North America are always remembered until now.

At the time of launching the story of A History of New York, the Dutch had already merged of the sovereign American nation. As an ethnic group, the Dutch had become a minority group, because the dominant group of the American nation was the British or Anglo-American descendents. However, in New York City itself until the early nineteenth century, the Dutch aura was still felt, there were still many New Yorkers who were descendents of Dutch colonists. Van Wyck Brooks $(1947,22)$ in his book The World of Washington Irving stated that as someone entered New York in the 1800s, one felt like the atmosphere in the Netherlands, because the churches and buildings were in Dutch style. He based his writings on William Dunlop's writings in his Journal in 1797 which described that along the banks of the Hudson were Dutch settlements. Although during the British colonization of New York area, around the early 18th century, many Dutch New Yorkers moved to Albany, New Jersey, and Sommerset County areas to escape from British pressure (Van der Sijs, 2009, 30).

The name Rip first appeared in Salmagundi in the part written by James Kirke Paulding, namely a name Rip van Dam (Paulding, 1983, 306). Andrew Burstein $(2007,201)$ stated that Irving harmonized the name Rip in Salmagundi with the clan of Cornelius Van Winkle who was the publisher of Irving's writings. Also in the notes section, Burstein (2007, 643) wrote 
that another alternative to the word Rip is R.I.P (Rest In Peace). This term is likened to a long sleep, and imagines something that is lost or dead.

Much criticism had been made of the short story "Rip Van Winkle", but no one has yet attempted to put this story into the context of its historical setting. In Bradley's writing (2007, 137-216) on the story of "Rip Van Winkle", Bradley makes a comparison between the main character Rip Van Winkle in Washington Irving's short story and Leroy Moffit the main character in Bobbie Ann Mason in his short story "Shiloh". These two figures are compared with the point of view of Feminist Criticism. Actually, the character of Rip Van Winkle had been analyzed by Judith Fetterley in her article The Resisting Reader: A Feminist Approach to American Fiction, published in 1978. In this article, Bradley compared the character of Rip highlighted by Fetterley with that of Leroy. Fetterley noted that female readers of American literature often search in vain in canon texts of sympathetic images of themselves. The character Dame Van Winkle become a major problem, Rip's wife is depicted as victim, enemy, and as the other. According to Fatterley, Dame Van Winkle is not a person, but a stereotype, a convention, and an abstraction, reduced to merely a brief narration about her role as a fierce, riotous, and ill-behaved wife. Irving portrayed the character of Dame Van Winkle as an opposite to the male characters presented in the story, especially the character of Rip Van Winkle. The same thing happened with Norma Jane, Leroy Moffit's wife in the "Shiloh" story. She got a bad image like Dame Van Winkle. Meanwhile, the main character Leroy Moffit was described as an ideal man as Rip.

In another criticism of Irving's short story, Ferguson (2005, 529-581) analyzed that Rip Van Winkle character was a character known as a cheerful character. He was a wanderer who traveled from Sleepy Hollow to the Kaatskill Mountains. But according to Ferguson, Van Winkel was actually a successful failure man. Rip Van Winkle's departure on a flop was a tremendous releasing. Rip went to the hills in order to momentarily avoid his angry wife, as well as the problems that arise in his village, but it turned out he was fallen asleep for twenty years. In other words, according to Ferguson, this showed how a person rejected responsibility in his environment. Rip was a symbol of American childhood and misplaced innocence. He was an adult who refused to develop and avoided it. Success was created through the story by describing Rip's return from his long sleep as an expression of the success of passing childhood to second childhood (old age) without having to go through the obligations of adulthood that were in between.

Martin Roth (1976, 248-255 ) discussed about Irving's short stories from Washington Irving's Sketch Book, "Rip Van Winkle" which had been examined from various angles by Roth, in terms of sociology, psychoanalysis, and comparative mythology. Even, various approaches to this story was also through Irving's previous work, namely A History of New York. According to Roth, the story was full of meanings and symbols. "Rip Van Winkle" is a humorous story set in contrast through the friendly and calm character of Rip, and the opposite was his fierce wife. This can be clarified as an analogy of two types of government, which is dominated by a woman and which is democratic.

From several writings about Rip Van Winkle, it can be seen that Rip is not seen as a representation of Dutch ethnicity in the United States. Although there are those who see the historical setting of this short story, it is not analyzed that refers to the Dutch ethnic identity in America. This article attempts to examine the story of "Rip Van Winkle" from Stuart Hall's theory of representation which states that representation can give meaning to an identity. The cultural identity of the Dutch people was represented through Washington Irving's view in the story of "Rip Van Winkle", so that the cultural identity of the community was built through a representation practice. Cultural identity is not something that is fixed and without problems. Cultural identity is a question of how we shape ourselves, which Stuart Hall (1997, 51-58) termed the process of becoming or being. Identity is always in process, and is formed through 
representation. This representation is in a continous process. Representation practices always imply the position from which something is written, described, or narrated. There are two thoughts about cultural identity, the first is cultural identity in the sense of a kind of collective culture which is shared in the same cultural code tied to historical experience. The second is an identity that is constantly in motion because of the ways we are positioned, and position ourselves.

The approach method used in this research is the New Historicism approach. This approach is used with consideration of the problems and objectives presented in the research, namely the representation of 18th century Dutch New York society which was used as a vehicle for constructing the myth of the New American nationality in the 19th century by Washington Irving. Historical background is needed to see and examine conflicts that occurred in the past as a context, then how the historical background affects the fictional text internally.

Questioning the relationship between text and history is an approach taken by New Historicism. New Historicism considers that a textual approach that focuses on text and aesthetic aspects is less able to see the relationship between the text and the world that produces the text. Whereas the world of imagination that was built by the author is a way to bring back, respond to, and participate in constructing reality (Gallagher \& Greenblat, 2000). Thus, the literary text cannot be separated from the influence of the world that is outside of the text.

New Historicism eliminates the boundaries between literature and non-literature, because it questions, if the whole culture is seen as a text, then everything can at least play a dual role at the level of representation as well as the level of events. Thus, it will be very difficult to make clear boundaries between what is a representation and what is an event. After all, maintaining boundaries itself is an event (Gallagher \& Greenblat, 2000).

New Historicsm views that both history and fiction are presented through representational acts. Hayden White (Wells, Burgess, \& (Ed)., 2000, p. 16) states that historical facts or facts indeed existed, but when they were written down, they contained selection and meaning that can comprise different versions. Gallagher and Greenblatt $(2000,19)$ state that New Historicism analysis involves a large number of knowledges. Thus, we can conclude that the methods used by New Historicism in approaching a work are various, not based on one method but a mixture of various approach methods. However, it remains based on the search for the past that is implied in literary texts by transcending the boundaries of formalist literature.

Based on the Representation theory and the New Historicism approach, the short story "Rip Van Winkle" was studied to explore how the representation of the Dutch New York was presented in this short story and how this ethnicity was positioned in the history of American culture.

\section{CHARACTER WHO DENIED OR SURMISED THE REALITY}

This "Rip van Winkle" story is one of the framed stories told by Knickerbocker in The Sketch Book. This story was obtained by the narrator of The Sketch Book, namely Geoffrey Crayon from Knickebocker's documents. Knickerbocker was Geofrey's friend. Before getting into the "Rip Van Winkle" story, Geoffrey explained that Knickerbocker was dead and Knickerbocker's documents fell into his hands. He reiterated the contents of the Knickerbocker documents, one of which contained the story of "Rip Van Winkle".

The character of Rip van Winkle was described as a simple man. He was a descendant of the valiant Van Winkle family during the time of Governor Peter Stuyvesant who was involved in the siege of Fort Christina ${ }^{i}$. According to Knickerbocker, Rip's character inherited only a few of the heroic characters of his predecessor, "He inherited, however, but little of the character of his ancestors" ("Rip Van Winkle", 770). This bit of information makes us refer back to the story of A History of New York which was narrated by the same narrator named 
Knickerbocker. The Van Winkle clan was indeed one of the soldiers during the Stuyvesant era in the story, the soldier that Knickerbocker jokes about, such as on this quote [...] - Then the Van Winkles of Haerlem, potent suckers of eggs, and noted for running of horses and running up of scores at taverns; they were the first that ever winked with both eyes at once (A History of New York, 631).

The character of the Van Winkle clan described by Knickerbocker in A History of New York as a family that has the courage to bet fate or gamble. Meanwhile, Rip van Winkle's character had inherited very little of this trait. By connecting the character of Rip van Winkle to his ancestors, Knickerbokcer's opinion about what traits of Rip ancestor passed down can be percieved. The whole story in "Rip Van Winkle" shows how the actual character of Rip. He had inherited a little of the brave traits of his ancestors, accordingly he had the opposite character, which was not willing to bet on fate.

The character of Rip van Winkle is a representation of the Dutch settlers in New York on the banks of the Hudson River, who lived simply, friendly, and ready to help anyone. They were still loyal to the customs of their predecessors. Those are the starting descriptions of Knickerbocker's story. However, there were problems encircle the character of Rip van Winkle before he went to Kaatskill and fell asleep there. The problems with his diminution fields, his wife who regard him an indolent man, and the discussions with his friends made him worry. The intricate situation in his village pushed Rip flee away to Kaatskill.

\section{THREE PERIODS OF RIP VAN WINKLE LIFE}

There are three periods depicting the life of the descendants of Dutch colonists in this story, namely before Rip fell asleep, when he fell asleep, and when he woke up. Before Rip went to Kaatskill and fell asleep there, The life of the village on the banks of the Hudson river was described as a small village that was very antique. It was built by some Dutch colonists during the reign of Governor Peter Stuyvesant around the 17th century. There were typical Dutch houses built with bricks sent from Holland with latticed windows and saddle-shaped roofs, and at the top of the roof there was a cock weather forecaster.

In the first period before Rip left to Kaatskill, the everyday life in the small village was described going slowly. On summer afternoons, some men would sit around telling unnecessary things, even they were listening to stories that made them sleepy. This shows that the small village life was very monotonous, and "peaceful" which was apparent because at that time the Dutch colony in America had turned under British rule. However, the discussion would be becoming more serious when suddenly an old newspaper arrived in their hands which was carried by the traveler. Opinions arising from these discussions would be controlled by their village chief, Nicholas Vedder.

However, this arisen opinion could turn into futile if suddenly Dame van Winkle came to ruin this meeting. Dame van Winkle did not even consider on the village chief that the village people respected. On the contrary, she accused the village chief of making her husband have a habit of laziness. Rip always obeyed and adhered his wife, Damme van Winkle, who was frequently angry and thought he was indolent, even though he had tried his best in cultivating the fields, in the text Rip was mentioned as an obedient hen-pecked husband. The character of Rip can be seen as a parable of the Dutch ethnic descendants living in America. They tried to obey and follow the British government. Every effort they had attempted to be devoted, but they were still considered as lazy people. This picture implies that the Dutch life was always under the control of British rule. Even if one of them became a leader, it was meaningless. Any opinion that arose from the minds of this minority community would be ended in vain.

Burstein $(2007,206)$ states that Rip's fierce wife is the parable of the late colonial tyranny of Britain. This implies figurative languages appearing throughout the surface of the text. 
Irving compared England to Rip's wife, the most obvious from the text is in the quote when Rip awakened from his sleep, governments had changed and Damme van Winkle was gone.

"[...] Rip, in fact, was no politician; the changes of states and empires made but little impression on him; but there was one species of despotism under which he had long groaned, and that was - petticoat government. Happily that was at an end; he had got his neck out of the yoke of matrimony, and could go in and out whenever he pleased, without dreading the tyranny of Dame Van Winkle. ("Rip Van Winkle", 783)

Here the character Damme van Winkle becomes a metaphor or parable of Great Britain's rule over what was once the colony of New Netherland. The Dutch-British relationship in one area was perceived to be a conjugal relationship which was always noisy, but the one in power was the woman. Irving in several of his fictions about the Dutch New Yorkers always equated the power of the British government as power in the hands of woman. The tyrannical power of the British always made the area of the former Dutch rule smaller and smaller. This is implied by the symbol for Rip's field, as in the quote below.

\begin{abstract}
In fact, he declared it was of no use to work on his farm; it was the most pestilent little piece of ground in the whole country; every thing about it went wrong, and would go wrong, in spite of him. His fences were continually falling to pieces; his cow would either go astray, or get among the cabbages; weeds were sure to grow quicker in his fields than anywhere else; the rain always made a point of setting in just as he had some outdoor work to do; so that though his patrimonial estate had dwindled away under his management, acre by acre, until there was little more left than a mere patch of Indian corn and potatoes, yet it was the worst-conditioned farm in the neighborhood. ("Rip Van Winkle", 771)
\end{abstract}

Rip fields have an overlap of literal and figurative meaning. The field was just a small field that was constantly collapsing its fences, as a metaphor for the territory occupied by the descendants of the Dutch colonists in America which was getting smaller and smaller because the boundaries were no longer clear. This situation shows what the fate of the Dutch colony in America was, which had no meaning anymore. At the same time, the Dutch New Yorkers were also marginalized.

The second period of Rip life was when Rip went to Kaatskillii. In this period, the actual picture of the Dutch ethnic life on the banks of the Hudson River was not literally recorded in the text, because the story focused on Rip who fell asleep only one day. This depiction of Rip in Kaatskill makes this story become a fantastic story, as ghosts appeared from the past. At Kaatskill, Rip met the ghosts of Dutch people dressed in ancient clothes from the days of Henry Hudson. Then, Rip slept for twenty years, but Rip felt that he had only slept for a day. After Rip awakened and headed back to his village, readers find out what happened. During the time he fell asleep, many events were missed. The new America experienced a war against Britain, then America got its independence. Some males of villagers had died, there was joined the revolutionary war, there was also become member of the congress.

The depiction of the falling asleep of Rip is a parable. Rip could not recognize the changes in space and time before his eyes, because he was still bounded by time and space in the past. Consequently, the time seems to stop for him. The twenty years when Rip was sleeping, the American population had spent their time by fighting against British rule, and after that enjoying the freedom from the results of independence. For Rip, he spent only one night with Dutch people who dressed in ancient style like the early days of the colonial occupation. Those people from the past met him in the valley of the Kaatskill mountains. He had watched the ancient Dutch people play the nine-pins ${ }^{\text {iii }}$. He enjoyed their game, and also enjoyed the typical Dutch liquor they brought.

At the surface level meaning of the text, the meeting between Rip and the ancient Dutch people creates a mystical impression, because he met people who had died long time a go. Nevertheless it is narrated, after a long time Rip actually enjoyed the atmosphere of the meeting. The sentence which states, "He even ventured, when no eye was fixed upon him, to taste the beverage, which he found had much of the flavor of excellent Hollands. He was 
naturally a thirsty soul, and was soon tempted to repeat the draft" ("Rip Van Winkle", 776). These sentences are the opening that this event has a connotative meaning. Rip drank a liquor that tasted very typical of the Netherlands from the bottles brought by the ancient Dutch people. He needed it, because his soul was actually very thirsty. "A thirsty soul" is not literal meaning. Rip was not thirsty in the real sense. These words have connotative meanings. He longed for the life from the periodes of ancient Dutch colony. It is like a feeling of nostalgia for the past. He had spent twenty years remaining engaged in that thought. Meanwhile, time and space outside of him moved rapidly without being able to endure it. When his consciousness recovered, he had fallen far behind the space and time that should have been.

For twenty years, Rip had tried to stick with his cultural identity, but it seemed as if in just one day everything was gone. Everything that clinged to him, his lifestyle, his social life was taken abruptly. He no longer recognized the people around him, not even himself. He did not realize that he was very old with a beard more than a foot long. This is figurative. In other words, the culture of the Dutch colonists was ancient and soon it would only become a historical document along with the death of the cultural heirs.

Unlike in A History of New York, Irving's "Rip Van Winkle" did not provide an exact date for the events. We have to estimate the year of the events based on the clues of the text, because the text does not mention the number of years clearly. The text only provides clues through the events that took place, such as the election, then the painting portrait was George Washington no longer King George III. With these clues, we can guess when the main character Rip van Winkle was alive, even though he was a fictional character in this story.

The tracing of the time in the mind of Rip was lost for so long and distant, he did not follow the war of the American revolution, also American independence; It means that Rip did not know when the government had changed. Another event in the story as a marker is when Rip returned to the village after he descended from the Kaatskill Mountains. In his changed village, the elections were being held divided into two opposite campaigns. From this event, it can be estimated the time span of Rip's falling asleep. The year the presidential election took place during the George Washington era was around $1796^{\text {iv }}$. Rip was asleep for twenty years, if it is counting down Rip went to Kaatskill and fell asleep around 1776. That year was the year of American independence and also the beginning of the revolutionary war in America against colonial Britain.

In fact, on closer examination, Rip's state of sleep is full of allegory. The village Chief Nicholas Vedder was dead. The text "Rip Van Winkle" says that the Chief of the Village died about eighteen years ago, It means that it was two years after Rip left for Kaatskill. If the presidential election after George Washington took place in approximately 1796, then the previous eighteen years would be around 1778. Two years after America gained independence in 1776, the village chief Nicholas Vedder was narrated have died. With the election benchmark taking place and Rip was sleeping for twenty years, we can calculate exactly when the village Chief had died.

Washington Irving always used the parable of the death of a leader as the end of power over a region. This can be seen in the government of the three governors of New Netherland as well who all died in the story of A History of New York he wrote. The death of the village Chief can be interpreted as a metaphor for the end of the area inhabited by the descendants of Dutch ethnicity, which has indeed shrunk. The territory has become part of the United States. This may imply that two years after America's independence, the Dutch community lost their ancestral cultural territory.

Meanwhile, Rip's friend, Brom Dutcher, went to war during the war of the American revolution. He reportedly died at Stony Point ${ }^{\mathrm{v}}$. However, there were also those who claimed that Brom Dutcher sank at the foot of Anthony's Nose ${ }^{\text {vi }}$. This hill is located northwest of the Hudson River. In other words, Brom Dutcher never returned from war. Brom Dutcher's 
character is a representation of Dutch ethnic descent who took part in the formation of America, because he fought against the British. Derrick Van Bummel, the school principal, also went to war, he even became General of the army. He later became a member of the congress.

The last two figures represent the Dutch who did not remain silent in the formation of the American nation. On the other hand, the figure of Rip Van Winkle is a representation of Dutch ethnicity who did not want to take part in the formation of this new nation. He remained attached to the past. As a result, the generation who chose a path like Rip felt the most loss of their Dutch cultural identity, while other Dutch descendants became Americans without feeling that they had lost their ethnic identity, but they participated in celebrating becoming a new nation.

The village inn owned by the leader Nicholas Vedder, the head of the village, where the men gathered to discuss all matters of importance or insignificance, had changed not only in form but also in owner. This inn is a symbol or an epitome. When the inn was turned into a hotel called the Union Hotel, it has connotative meaning that the house and the name of the hotel are a symbol of the change of power. Power over the territory already belongs to the Union, namely the United States.

It used to be a village inn, now a hotel. It is not just the name that had changed, but the whole building. The inn building was turned into a large wooden house, with large windows. It was no longer a brick house with a saddle roof. The large tree near the inn where the village men used to take shelter with the village chief spoke gossip, had been replaced by a flagpole that represented a collection of stars and stripes, the United States flag. The big tree and the American flag are placed in the same position. The relationship between the characteristics of a large tree and a flag can be interpreted as the meaning of a shelter for residents.

For more details. We look at a quote from the view of Rip van Winkle when looked at the inn with a strange feeling.

\footnotetext{
He now hurried forth, and hastened to his old resort, the village inn-but it too was gone. A large rickety wooden building stood in its place, with great gaping windows, some of them broken and mended with old hats and petticoats, and over the door was painted, "The Union Hotel, by Jonathan Doolittle." Instead of the great tree that used to shelter the quiet little Dutch inn of yore, there now was reared a tall, naked pole, with something on the top that looked like a red night-cap, and from it was fluttering a flag, on which was a singular assemblage of stars and stripes - all this was strange and incomprehensible ("Rip Van Winkle", 779)
}

From the above quotation we can see that the big, shady tree is made figurative. Under that tree there was once a small quiet Dutch style inn. The inn was located in a small area, but the residents were still able to calmly interact with the lifestyle they had been used to. The big tree was both a protection and a barrier against the scorching sunshine when they sat under it. In another part of the story, the village chief, Nicholas Vedder, could sit in the shadow of the tree all day, only shifting slightly when the sun's rays hit him. This big tree is a parable for a shelter for great powers that they can still avoid without being disturbed. The tree was like a village where they took shelter where the cultural heritage of the Dutch colonists was still protected from the reach of British rule, which at certain moments they could still avoid by taking refuge in their village.

The characteristic of Irving's story always anchored his story to historical events. It can make a link draw between the story and what happened in the history, even though the story is fiction. The first election event in the United States was an event that had ever occurred in American history, Irving attributed it to the story of "Rip Van Winkle". The event illustrated how the situation of a new nation enjoying the independency liberated from the British rule. However, during that time there was also a lot of frictions in the American government. This can be seen when someone asked Rip where he was on the side of either Federal or Democrats $^{\text {vii }}$. The United States government at that time had two different political camps. 
Amid the chaos of different views in government, there were parts of American decendents who were confused. This is represented by the figure of Rip. Not only did he not understand political parties, but he also did not understand why things had to change. To be exact, Rip could not accept that drastic changes.

Actually, if it was retraced to the text from the moments before Rip went to the Kaatskill mountains to go away from his village, we find that Rip had reasons to leave, besides avoiding his wife who was always angry, and pressed him. The inn of Nicholas Vedder, the cief, was no longer a pleasant place to escape from his wife's pressure, because the gossip they discussed was no longer trivial things. They discussed the contents of the old newspaper which had arrived at their hands by accident. This description was stated in the text of the story, but what was the content of the newspaper, the reader never knows, because it is not stated clearly in the text as the citation below.

[...]But it would have been worth any statesman's money to have heard the profound discussions that sometimes took place when by chance an old newspaper fell into their hands from some passing traveller. How solemnly they would listen to the contents, as drawled out by Derrick Van Bummel, the schoolmaster, a dapper, learned little man, who was not to be daunted by the most gigantic word in the dictionary; and how sagely they would deliberate upon public events some months after they had taken place ("Rip Van Winkle", 772).

If we relate all events in the text by relating them to the events in the American history, then we can find out what was in the newspaper that made Rip stay away from the village. The year he went to the Kaatskill mountains was the year of independence and the start of the American revolution against Britain. It can be assumed that the independence and the American Revolution were the contents of the newspapers discussed by Rip and his friends. Rip avoided the incidents. After that American independence was filled with turmoils in a government that Rip did not exist, because he fell asleep. It is a metaphor that Rip did not keep up with what was happening. He did not come along with the important events in the American History. All the events that happened around him were not considered by him. He presumed them never happened, because he was still influenced by feelings of nostalgia for the culture of his ancestors. Until at one point, in a time that was like one night, he was faced with a reality that he could not longer deny. Time and space changed, until he could no longer recognize it.

The third period was the period when Rip returned to his village after a very long sleep. During this period, the life and the identity of the Dutch in America, the descendants of the colonists, were disappeared. The loss of the identity of this ethnic was marked by the collapse or loss of these distinctive ethnic buildings ${ }^{\text {viii }}$. Rip's village had disappeared, replaced with new buildings. Even the people Rip knew were gone. The atmosphere of a typical Dutch small village is gone, only a new atmosphere completely extraneous to Rip.

\section{DISAPPEARING CULTURAL IDENTITY}

Those who feel very attached to their ancestral culture have always experienced shaking of identity as experienced by the figure of Rip. However, for the generations after Rip, it was no longer a problem, because they consciously or not had adapted to their environment even when their parents who upholded their ancestral culture were still alive. This is illustrated by Irving through Rip's view of his children who no longer know the rules. The children were more likely to follow the character of their mother, Dame van Winkle.

Rip's children were unaware and did not feel this shock of identity. Instead, they joined in the joy of becoming a new nation. The culture of their Dutch ancestors remains a story that may or may not be believed. At this point, Irving through his narrator actually showed that in the midst of the euphoria of the formation of a new nation, there was an ethnic group that felt that they had lost everything, lost their place, their culture, and their material culture. 
Meanwhile, on the other hand, the young generation of Dutch descents were no longer like their fathers. They were rude and arbitrary from Rip's point of view as an older generation Dutch New Yorker. The differences in attitudes between the father and son show that there had been differences in views and attitudes between the father and his descendants. The Dutch descendants of New York at that time did not care anymore about their old culture, they were more imitating the attitudes of their rulers, in this case England. This suggests that Rip's children were just like their mother.

His identity problem became complicated when Rip returned from the Kaatskill Mountains. His safeguard against the cultural identity inherent in him was shaken, because the area that supported the cultural space of the Dutch colonists had disappeared. It was remaining only was his descendants who had different identities. They had already become Americans and they no longer knew and recognized their father who was old. It means that they no longer recognized the cultural identity of their ancestors because their identity had changed to become Americans.

Rip begins to be confused with his identity. On the one hand, he was the Dutch descent who still maintained the identity of their ancestral cultural heritage, on the other hand things had changed completely. This can be seen in its impact on the younger generation who no longer cared who and where their descendants came from. Meanwhile, Rip was very adamant about the culture of the Dutch colonists in the past.

The important thing in this story is that this loss of identity is preceded by the disappearance of cultural space, because the geographic place or area remains there and the ethnicity remains in the same place, not going anywhere. Ironically, when it was still under British rule, Dutch culture still existed even though it was only on the margins or on the periphery. Nevertheless, when America achieved precisely its independence, when freedom was achieved, Rip and the villagers lost everything. Losing the territory where they took shelter and protection, also they lost their daily cultural customs, consequently Rip felt like he was in a strange place even though he recognized his village. His village had never moved, it means that he did not go wrong or got lost, but the atmosphere had changed. The contents of the territory had been replaced by different cultures and powers. Finally, Rip became someone who looked like an odd antique from the past. His identity was an old man descended from the Dutch colonists but had no place in the region, space, and time when the independence was achieved. The quote below shows how Rip felt when he learned that America was independent.

\footnotetext{
How that there had been a revolutionary war - that the country had thrown off the yoke of old England - and that, instead of being a subject to his Majesty George the Third, he was now a free citizen of the United States. Rip, in fact, was no politician; the changes of states and empires made but little impression on him; but there was one species of despotism under which he had long groaned, and that was-petticoat government. Happily that was at an end; he had got his neck out of the yoke of matrimony, and could go in and out whenever he pleased, without dreading the tyranny of Dame Van Winkle. Whenever her name was mentioned, however, he shook his head, shrugged his shoulders, and cast up his eyes; which might pass either for an expression of resignation to his fate, or joy at his deliverance ("Rip Van Winkle", 783).
}

On the one hand, he was released from the power of Damme van Winkle, it means that the Dutch descents were released from the confines of British rule. However, at the same time in the free air of independence, the Dutch people actually lost their identity. Rip became a free man, he could enter and exit the country without surveillance, but at the same time his culture was disappeared. Not only were the Dutch marginalized, but they were almost destroyed their identity. The remnants of their Dutch cultural identity were only left on the same old people as Rip, who were just waiting to die. Meanwhile, the people around them did not know about the culture of the colonists.

The story tells that Rip ended up staying with his daughter, whom he left behind when he went to Kaatskill. His daughter was named Judith Gardenier, a name for a mixture of Dutch- 
American with British roots. His first name is commonly used for Dutch girls, but his last name is a name of English descent. She no longer used the Van Winkle family name. Family name is one of an indicator of Dutch identity ${ }^{\text {ix }}$, so it can be a symbol that the descendants of the Dutch colonists after Rip started to shed their cultural identity, but it can also be seen that the character Judith married British descent so that she got this name.

The descendants of Rip have used their American identity. This shows that some of the descendants of the Dutch colonists or the younger generation perhaps have abandoned their ethnic identity. It can be assumed that Irving has another goal by showing a mixed DutchEnglish name with no surnames. In the name of nation formation, the Dutch descendants in America did not lose their identity through the family name in the realities of New American life, but the loss of this family name as a metaphor for them lost their culture. The Dutch descents no longer recognize their culture, in the text it is associated with the event that Judith did not recognize her father at all when she met an old Rip who returned from Kaatskill.

In the text "Rip Van Winkle", there are three names of Rip, namely the old Rip van Winkle; Young Rip who had inherited his mother behaviors; and the innocent baby boy Rip on the holding of Judith Gardenier. This is a picture of three generations of Dutch New Yorkers. Old Rip was tied to the culture of the past, young Rip was influenced by British culture, baby Rip was a kid who did not know anything about his country, the United States.

Washington Irving showed that Rip van Winkle as a representation of how an ethnic group has lost its identity. Ironically, it happened when independence and the formation of a new nation were beginning. Rip was the last descendant before the Dutch culture completely disappeared from the United States, because his children had become a new nation that must be reminded or reintroduced to the culture. Although there are those who believe, but there are also those who do not believe in Rip's story about the past. In other words, the original culture of the descendants of the Dutch colonists remained only a story, no longer inherent in their descendants. Rip became a legend about New York's Dutch ancestry in the past.

The change was a necessity for a nation entering a new chapter in the life of its nation. Irving did not imply negative or positive about this event, when commitment to the nation occurs, then this is something normal or automatically if the cultures that once existed in America are eroded. On the contrary, yet Irving implicitly gave an assessment to the next generation, namely the young Rip who was influenced by the style of their mother, Damme van Winkel. Basically, he was the representation of the younger generation who were the pioneers of this new nation, but they were influenced by the British who were once the tyrant.

This criticism of British influence can be seen in the parable description of a wooden house built in the village of Rip, as a substitute for a typical Dutch inn. The hotel was described as a large, shaky wooden building, which had large window gaps, but broken here and there, patched up with worn hats and women's skirts, "A large rickety wooden building stood... with great gaping windows, some of them broken and mended with old hats and petticoats, [...]" ("Rip Van Winkle", 779). This written sentences fulfills the requirements of the complete sentence when they are read, but the meaning of the description is somewhat confusing, so this sentence is not in a literal sense. The large building, which was a symbol of American power, was actually still shaking. Although, it had such a large territory, this power still had many gaps that were trying to be patched here and there with "old hats and petticoats".

"Old hats and petticoats" has still actually a connotation meaning that refers to British rule, because there is an expression that a bad hat is the same as meaning bad person, then petticoats government means government under women's power. Thus, old hats and petticoats refer to outdated aristocratic rule. Therefore, the New America at that time was actually a sovereignty over a large area that was still shaky, here and there in its government still using the British style. The real colonial rule was actually opposed by the United States. 
The implication also appears on the owner of the hotel Union which is represented by a person named Jonathan Doolittle. The name is a representation that refers to the Yankees, who were the British descents who lived in the New England region. The word "Doolittle" when translated, could mean "to work a little". If we look for other connotations, it can mean that America at that time was none other than the Yankee domination who accepted the relay of power by taking refuge in the American flag. In other words, the dominance of British descents in a new nation called the United States of America with government regulations that adopted British rule. In fact, this was Irving's critique of the New American government.

Irving showed that there was a disappearing culture that once existed on American soil, as well as he criticized the New America which was still influenced by the British which they actually fighted against. Irving seemed to show that New America should not be like that, letting a culture in process of disappear, and letting one particular culture become dominant. However, Irving also did not provide a solution to how the New America should respond to this situation. More than that, what the picture of New America really was and should be, Irving did not give a way out explicitly or implicitly for this.

\section{CONCLUSION}

The story of "Rip Van Winkle" is decorated with a fantastic story with the sudden appearance of a supernatural event in a real world, giving the story a strange impression. However, on the other hand, by tracing the theory of representation and the New Historicism method, the events presented by Washington Irving can be interpreted as metaphors and symbols of an ethnic group that had lost its identity and culture.

Washington Irving seemed to describe that in America there were a community that was confused about how to behave when independence face right in front of the eyes, but at the same time their ethnic culture was lost. In addition, this freedom cannot be said to be a complete freedom over the pure ideas of a new nation, but it was still clinging to the old ideas of the tyrants of the past that they really wanted to release.

In addition, through "Rip Van Winkle", Washington Irving wanted to show that the Dutch community, which had become a minority community during the British rule, had different views in their attitude towards independence. The figures of Van Bummel and Brom Butcher represented the figures who wanted to be involved in the formation of the new nation; while the one who was surrender to the situation was Nicholas Vedder; Rip represented those who were bound with the past. Moreover, Rip van Winkel is the main character in this story, so it can be said that he represented most of the Dutch New Yorkers who behaved like this.

Rip wanted his ancestral culture still remain attached to him, but he also wanted to be independent. He did not want drastic changes, because in fact the formation of a new nation was not accompanied by new ideas, instead it eliminated one of the cultures that had existed in America and put forward the dominant culture. The description of the Dutch village that disappeared, and the Hotel Union and its owners were seen by readers through the eyes of the figure of Rip, where Irving simultaneously criticized Union.

The character of Rip van Winkle is a representation of a marginalized community. The marginalized Dutch New York community had become a historical fact. Since British colonial times, they had been suppressed, the American independence should have been the answer. The freedom in the true sense that protects all ethnicities. However in fact, that independence belongs to Yankees, the ethnic Dutch New Yorkers were not part of it all, even though they were there and some of them play a role in the independence, but at the end they only become the cheerd part when the new nation was formed. This is represented by the character Judith who is also happy in the crowd in the election. The Dutch ethnicity was culturally displaced. This picture shows an ambiguous description, one side Rip is a representation of Dutch 
ethnicity who did not accept the fact that they had become a new nation, the other side on the contrary they actually could predict the future that their culture will not have a place in the realm of American independence. This can be seen when Rip was not at all impressed with American independence, because in fact the Dutch New York culture that had existed for hundreds of years in that country was vanished. The culture is left behind only in the story that may be believed, or maybe not.

In "Rip Van Winkle, Rip was lazy from Damme van Winkle's point of view, but Rip distancing himself from his village, becoming alienated by new situations was from the point of view of Knickerbocker, the narrator. Rip is the main character, he is the main representation of Dutch ethnic New Yorkers who were lazy and did not accept reality, and this paradigm is legendary in America. Meanwhile, the figures such as Brom Butcher who fought for American independence, even died in the war, and Derrick Van Bummel who joined the war and became a member of the congress just passed by, because they were only subordinate figures in the story. They were not described in detail, so that the ethnic Dutch who fought for American independence and became officials in the American government were not legendary. The legendary one is Rip van Winkle who is lazy and reluctant to become an American, and that paradigm sticked on the Dutch New Yorkers.

\section{REFERENCES}

Baga, M. (2020). Corruption, Officials' Attitude, and Mechanism of Officials Election in A History of New York by Washington Irving. Journal NX-A Multidisciplinary Peer Reviewed Journal, 236-250.

Baga, M., \& Budianta, M. (2018). Contested Representation of Dutch Americans in Washington Irving's A History of New York. In M. Budianta, M. Budiman, A. Kusno, \& M. Moriyama, Cultural Dynamics in a Globalized World (pp. 259-264). London: Routledge, Taylor and Francis Group.

Bradley, E. L. (2009). Knickerbocker: The Myth behind New York. New Jersey: Rutgers University Press.

Bradley, P. L. (2007). “'Rip Van Winkle' and 'Shiloh': Why Resisting Readers Still Resist”. Critique, 137-216.

Brooks., V. W. (1947). The World of Washington Irving . Great Britain: J.M. Dent \& Sons Ltd. .

Burstein, A. (2007). The Original Knickerbocker: The Life of Washington Irving. . New York: Basic Books.

Cook, J. A. (1995). “Prodigious Poop": Comic Context and Psychological Subtext in Irving's Knickerbocker History. Nineteenth-Century Literature, 483-512.

Ferguson, R. A. (2005). Rip Van Winkle and the Generational Divide in American Culture. Early American Literature, 529-581. .

Funk, E. P. (2005.). Knickerbocker's New Netherland: Washington Irving's Representation of Dutch Life on the Hudson. In G. Harinck, \& H. Krabbendam, Amsterdam-New York Transaltlantic Relations and Urban Identities Since 1653 . Amsterdam: VU Uitgeverij.

Funk, E. P. (2009). From Amsterdam to New Amsterdam: Washington Irving, The Dutch St. Nicholas, and The American Santa Claus. In M. D. Shattuck, Explorers Fortunes and Love Letters: A Window on New Netherland (p. 102). Albany: New Netherland Institute.

Gallagher, C., \& Greenblat, S. (2000). Practicing New Historicism. Chicago: The University of Chicago Press.

Hall, S. (1997). Cultural Identity and Diaspora". In K. W. (Ed.), Identity and Difference: Cultures, Media and Identities (pp. 51-58.). London: : Sage Publications. 
Irving, W. (1983 ). A History of New York: From the Beginning of the World to the End of the Dutch Dynasty in Washington Irving: History, Tales and Schetches. New York: Literary Classics of the United States, Inc., .

Irving, W. (1983). Rip Van Winkle. In W. Irving, Washington Irving: History, Tales and Schetches. (pp. 767785). New York: Literary Classics of the United States, Inc.

Kunitz, S. J. (1977.). American Authors 1600-1900, VIII edition. . New York: The H.W. Wilson Company.

Pancost, D. W. (1987.). Washington Irving”. In American Literary Critics and Scholars, 1800-1850 . Detroit, Michigan: A Bruccoli Clark Layman Book.

Paulding, J. K. (1983). Salmagundi No. XVII. In W. Irving, W. Irving, \& J. K. Paulding, Salmagundi (pp. 299306). New York: Literary Classics of the United States.

Paulding, James Kirke. (1983). Salmagundi No. XVII. Dalam W. Irving, \& J. Irving, Salmagundi (hal. 299-306). New York: Literary Classics of the United States.

Ringe, D. A. (1967). New York and New England: Irving's Criticism of American Society. American Literature, 455-467.

Roth, M. (1976). Comedy and America: The Lost World of Washington Irving. New York: Kennikat Press Corp.

Van der Sijs, N. (2009). Cookies, Colestaw, and Stoops: The Influence of Dutch on The North American Languages. Amsterdam: Amsterdam University Press.

Wells, R., Burgess, G., \& (Ed)., R. W. (2000). Neo-Historicism: Studies in Renaissance Literature, History and Politics. Cambridge: D. S Brewer.

\footnotetext{
i Fort Christina was a Swedish fort on the South River of Delaware. The New Netherland colony could not accept the construction of a New Sweden colony in the area of Delaware, because the area was considered still belong to the New Netherland colony. The area became to Sweden's own area because former New Netherland leader Peter Minuit who was dismissed by The Dutch West India Company cooperated with the Swedish nation to set up a trading post in the area. This provoked the anger of the leaders of New Netherland.

ii Kaatskill, The Catskill Mountains, an area in New York State northwest of New York City and southwest of Albany

iii Nine-pins: game in which a ball is rolled along the floor at nine bottle-shapes pieces of woods. (Oxford Advanced Lerner's Dictionary of Current English, 1984)

iv George Washington chose to resign from the presidency in 1796 because he was tired of domestic political conflicts that had divided America into two opposing party camps, namely Federalists and Republicans.

${ }^{v}$ Stony Point was a war zone during the American revolution which is located west of the Hudson River. This area was a frequent stopping point for George Washington's army.

${ }^{v i}$ Anthony's Nose was the nickname provided by Stuyvesant to the hillside at Dunderberg that is shaped like a cape, according to Knickerbocker's story in A History of New York. In the story "Dolph Heyliger", the character Dolph passes through these hills when going to Albany. This hill is located northwest of the Hudson River.

vii The text of "Rip van Winkle" referred to Federal and Democratic. If it is traced back to the history, the names of the parties at that time were Federal and Republican-Democratic, because the background in the text occurred at the last of George Washington's administration.

viii See, Joseph Manca, "Erasing The Dutch: The Critical Reception of Hudson Valley Dutch Architecture, 16701840". Going Dutch: The Dutch Presence in America, 1609-2009 (Leiden: Koninklijke Brill NV, 2008), 5984. From 1750-1850, many buildings of Dutch ethnic heritage in New York were disappeared .

${ }^{\text {ix }}$ Famous Dutch surnames in America include Van Buren, De Roosevelt, Vander Bilt, Van Zandt and so fort.
} 